CIVICS EDUCATION AND SOCIAL SCIENSE JOURNAL(CESSJ)

Volume 3 Nomor 1 Edisi Bulan Juni 2021

\title{
ANCAMAN BULLYING Noktah Hitam Pendidikan Karakter
}

\author{
Maryam B. Gainau ${ }^{1}$, Yakob Godlif Malatuny, ${ }^{2}$ Lenny N. Elwarin ${ }^{3}$ \\ Sekolah Tinggi Agama Kristen Protestan Negeri Sentani \\ Email: maryamgainau@stakpnsentani.ac.id ${ }^{1}$,yakobgodlifmalatuny@stakpnsentani.ac.id ${ }^{2}$ \\ lennyelwarin@gmail.com ${ }^{3}$
}

\begin{abstract}
ABSTRAK
Tulisan ini bertolak dari kerisauan peneliti terhadap fenomena bullying yang terus terjadi dan meningkat setiap tahun sehingga menyita perhatian banyak pihak. Bullying menjadi bukti noktah hitam pendidikan karakter dalam beberapa dekade terakhir. Penelitian ini bertujuan untuk mengidentifikasi dan mencari solusi atas permasalahan ancaman bullying sebagai noktah hitam pendidikan karakter di SMP Negeri 4 Sentani. Pendekatan yang digunakan dalam penelitian ini adalah kualitatif dengan menggunakan metode studi kasus. Hasil penelitian menemukan bahwa, (1) pendidikan karakter yang diterapkan belum memiliki daya tawar yang berharga bagi pembentukan karakter seluruh warga sekolah. (2) pengajaran pendidikan karakter di sekolah masih mengandalkan bentuk pengajaran nilai-nilai dalam pelajaran Pendidikan Kewarganegaraan. (3) pendekatan keteladan baik pola berpikir dan bertindak sesuai dengan nilai dan norma belum efektif dipraktikan oleh guru. (4) bullying sebagai tindakan agresif secara verbal, fisik, atau psikologis yang berulang setiap waktu dan berdampak negatif bagi korban. Kesimpulan yang dapat ditarik dalam penelitian ini adalah sekolah sebagai garda terdepan dalam menanamkan karakter baik kepada para pelajar mesti lebih efektif dan efisien dalam menginternalisasikan nilai, moral, dan sikap yang berkeadaban mulya kepada setiap generasi bangsa serta menerapkan berbagai model, pendekatan, dan program pendidikan karakter di sekolah secara berkesinambungan.
\end{abstract}

Kata Kunci: Bullying, Noktah Hitam, Pendidikan Karakter

JORNAL PROGDI PPKn, FKIP UNIVET BANTARA SUKOHARJO BEKERJA SAMA DENGAN ASSOSIASI PROFESI PENDIDIKAN PANCASILA DAN KEWARGANEGARAAN (AP3KNI) JAWA TENGAH 
CIVICS EDUCATION AND SOCIAL SCIENSE JOURNAL(CESSJ)

Volume 3 Nomor 1 Edisi Bulan Juni 2021

\title{
THE THREAT OF BULLYING Black Spot Character Education
}

\begin{abstract}
This paper is based on researchers' concerns about the bullying phenomenon which continues to occur and increases every year so that it has caught the attention of many parties. Bullying has become evidence of the black point of character education in recent decades. This study aims to identify and find solutions to the problem of the threat of bullying as a black point for character education in Junior High School 4 Sentani. The approach used in this research is qualitative using the case study method. The results of the study found that (1) the character education that was implemented did not have valuable bargaining power for all school members. (2) teaching character education in schools still relies on the form of teaching values in Citizenship Education lessons. (3) exemplary approaches both patterns of thinking and acting by values and norms have not been effectively practised by teachers. (4) bullying is a verbal, physical, or psychological aggressive action that repeats itself every time and harms the victim. The conclusion that can be drawn in this study is that schools as the front guard in instilling good character in students must be more effective and efficient in internalizing values, morals, and civilized attitudes to each generation of the nation and applying various models, approaches, and character education programs in school on an ongoing basis.
\end{abstract}

\section{Keywords: Bullying, Black Spot, Character Education}

\section{PENDAHULUAN}

Tema tentang ancaman bullying sebagai noktah hitam pendidikan karakter amat menarik dan penting untuk dikaji, menilik beberapa persoalan mendasar. Kesatu, terdapat jurang lebar antara idealitas dan realitas pendidikan karakter dalam dunia pendidikan dewasa ini. Praktik kehidupan yang berciri anti karakter-baik telah menjamur diantara anak bangsa. Meski generasi bangsa ada yang terlahir di masa kemerdekaan, bebas menikmati pendidikan yang sudah dijamin pemerintah, namun mereka tidak steril dari pahit getirnya tindakan bullying (Malatuny, 2020: 95). Bullying merupakan tindakan yang tidak terpuji karena mengandung kekerasan.

Data dan hasil riset dalam empat tahun terakhir membuktikan bahwa, tindakan bullying belum dapat ditanggulangi secara saksama oleh warga sekolah. Sakdiyah, dkk mencatat (2020: 120) data dari Komisi Perlindungan Anak Indonesia 
(KPAI) terkait perilaku bullying di Indonesia pada bulan Mei 2018 bahwa telah terjadi 161 kasus bullying dalam lingkungan sekolah. Riset Prasetyo (2019: 2), menemukan keresahan warga atas kasus yang dipertontonkan oleh kalangan pelajar seperti menyimpang dari norma, tindak bullying salah satunya.

Hasil riset Roberts (2019), yang diuraikan dalam disertasinya di Universitas Cambridge menekankan perihal bullying yang telah menjadi perhatian internasional; khususnya bahaya yang ditimbulkan dari bullying terhadap para pelajar dalam lingkungan pendidikan, bahkan muncul kekhawatiran internasional tentang fenomena bullying. Studi dari Nafingah dan Suroso (2020: 166), menemukan persoalan bullying telah mendunia, hampir setiap orang menjadi pelaku maupun korban dari bullying termasuk di sekolah. Riset Ersotelos, dkk (2021: 3) di Inggris Raya baru-baru ini menjelaskan bullying menjadi persoalan lokal dan internasional yang secara konsisten berdampak negatif pada korban. Kajian Anggraini dan Ridha (2021: 13), menegaskan perilaku bullying masih terjadi di lingkungan sekolah, disiplin warga sekolah yang rendah menjadi salah satu penyebab.

Kedua, pendidikan formal sekarang ini belum dapat menjamin keamanan dan kenyamanan anak-anak belajar sesuatu yang baik-baik. Supardan, (2011: 315) mencatat, di samping sekolah yang tidak jauh berbeda dengan kursus-kursus di pinggir jalan yang mengabaikan masalah moral sehingga mencoreng pendidikan dalam mewari nilai-nilai luhur (transmitif) yang diharapkan banyak pihak. Lebih lanjut, kata Supardan (2003: 588) pergeseran dunia pendidikan tidak membawa pada keseimbangan yang diharapkan. Ibarat sebuah "pabrik" yang hanya bekerja atas dasar mekanis, mengabaikan aspek moral dan karakter, dimana anak-anak hanya dipacu mengejar uang. Peran guru di sekolah hanya "mengajar" dan tidak lagi "mendidik".

Akibatnya, Parrott (2000: 17) melihat kini terasa susah mencari pelajar yang jujur, bersahaja, sederhana, bertanggung jawab, kritis, dan kreatif-inovatif. Belum lagi, dalam temuan Suzet, dkk (2015) bahwa guru kerap mengabaikan tindakan bullying diantara para pelajar di sekolah. Padahal bullying telah menjadi masalah serius dan guru tidak menyadari besarnya dampak penurunan terhadap kesehatan mental, baik jangka pendek maupun panjang dari para korban bullying. Lebih lanjut, kata Budimansyah (2010: 83) yang lebih tragis, anak-anak kita yang masih di bangku sekolah pun sudah dapat saling menyakiti di jalanan, saling mencurigai, misalnya dengan yang berbeda etnis dan agama. Dalam catatan Lickona (1991: 20), dari sekian banyak masalah karakter yang tengah menjadi perhatian sekolah, tampaknya tidak ada masalah yang lebih mengkhawatirkan daripada masalah kenakalan diantara pelajar. Kondisi seperti ini meyakinkan kita bahwa, hampir semua sekolah tidak dapat menjamin keamanan dari bahaya perilaku bullying.

Ketiga, implementasi pendidikan karakter di sekolah menjadi hal yang amat urgen dilakukan sebuah bangsa agar dapat mempertahanan eksistensinya. Sebab, membangun jiwa adalah membangun karakter manusia dan bangsa (Budimansyah, 
2010: 1). Sayangnya, guru sebagai salah satu aktor kunci dalam menghitamputihkan nasib karakter anak bangsa belum efektif melaksanakan pembaharuan dari berbagi keterbelakangan (transformatif). Wardah (2020: 184), menggambarkan, lingkungan sekolah bagi sebagian siswa ternyata tidak selalu nyaman dan menyenangkan, bahkan justru membuat mereka stres, cemas dan takut. Tindakan bullying menjadi masalah utama.

Inilah yang dikeluhkan Supardan (2011) dalam karya Mengintip Bahaya Kekerasan Sebagai Ancaman Pendidikan Karakter Bangsa dan Hasyim (2011) dalam karya Gerakan Membangun Karakter Bangsa bahwa "potret pendidikan bangsa kita sekarang ini sungguh memprihatinkan dan gagal dalam membangun karakter bangsa yang bermartabat”. Hati-hatilah, sebab keruntuhan sebuah bangsa ditandai dengan semakin lunturnya tata nilai dan karakter bangsa, walaupun secara fisik bangsa masih berdiri tegak.

Dengan demikian, aktivitas sekolah tidak boleh terus-menerus terjebak dalam rutinitas pembelajaran yang melembagakan tradisi yang kering dengan guru sebagai pusat pembelajaran dan mengabaikan proses aktualisasi diri dan pembangunan karakter anak bangsa (Sofyan, 2011:279). Untuk proses pembelajaran yang terutama tidaklah kemampuan sesuatu wacana bahan ajar serta gundukan kenyataan, melainkan perlunya keserasian, serta konsistensi nilai- nilai itu dibudayakan. Bukan sekedar nasihat yang disampaikan, melainkan perlunya kesesuaian antara ucapan dan perbuatan. Perlu keteladanan yang konsisten, adanya keseimbangan bahwa nilai-nilai yang mulia itu benar-benar dijunjung tinggi dan diamalkan terutama diteladankan guru dalam kesehariannya.

Sekolah sebagai suatu institusi sosial, harus memberlakukan suatu sikap moral dengan meminta para siswa untuk patuh kepada para guru, melarang siswa untuk tidak boleh bertengkar, memberikan hukuman bagi siswa jika berbuat curang, dan lain-lain. Di samping itu, para guru mesti memberi keteladanan kepada siswa seperti bersikap adil, menghargai, dan peduli (Lickona 1991: 46). Karena, setiap anak bangsa memasuki pintu gerbang pendidikan mesti mencerminkan kehidupan yang penuh kebajikan (the virtuous life) yaitu kebajikan terhadap diri sendiri (selforiented virtuous) seperti pengendalian diri (self control) dan kesabaran (moderation); dan kebajikan terhadap orang lain (other-oriented virtuous) seperti kesediaan berbagi (generousity) dan merasakan kebajikan (compassion) (Lickona, (1991: 73).

Secara substantif terdapat tiga unjuk perilaku (operatives values, values in action) yang satu sama lain berkaitan yakni moral knowing, moral feeling, and moral behavior. Ditegaskan lebih lanjut bahwa karakter yang baik terdiri atas proses psikologis knowing the good, desiring the good, and doing the good-habit of the mind, habit of the heart, and habit of the action. Karakter dimaknai sebagai kualitas pribadi yang baik, dalam arti tahu kebaikan, mau berbuat baik, dan nyata berperilaku baik, yang secara koheren memancar sebagai hasil dari olah pikir, olah hati, olah raga, olah rasa dan karsa. 
Karakter baik di atas mesti membudaya dalam kehidupan warga sekolah, agar iklim sekolah tidak tercemar oleh tindakan bullying. Dalam membudayakan karakter baik dimaksud, tidak semudah membalik telapak tangan. Diperlukan kegotongroyongan atau usaha bersama dari semua pihak untuk membiasakan karakter baik ini dalam tindakan keseharian. Namun, kenyataanya hal ini belum diupayakan secara oleh berbagai pihak terutama warga sekolah.

Berdasarkan studi awal yang dilakukan oleh peneliti di SMP Negeri 4 Sentani, ditemukan bahwa tindakan bullying masih terus terjadi diantara warga sekolah. Pengaruh negatif dari lingkungan keluarga, sekolah, media massa, dan teman sebaya menjadi faktor penyebab. Bentuk bullying yang dilakukan pelajar antara lain. Kesatu, bullying fisik seperti menampar, menginjak, dan menjegal. Kedua, bullying verbal seperti menjuluki, meneriaki, memaki, menghina, mempermalukan di depan umum, menuduh, menyoraki, menebar gosip, dan memfitnah. Ketiga, bullying mental/psikologis seperti memandang sinis, memandang penuh ancaman, mendiamkan, mengucilkan, memelototi dan mencibir. Tidakan yang tidak terpuji seperti tentu banyak berdampak negatif pada perkembangan fisik dan psikis pelajar.

Mempertimbangkan kenyataan pahit yang ada, maka tema dalam penulisan ini amat menarik dan penting untuk dikaji. Karena, penulis yakini bahwa akan terjadi banyak kerugian apabila tema dalam penulisan ini tidak diteliti dan dicarikan solusi. Beragam masalah yang telah dijabarkan sebelumnya akan dijawab dalam penelitian ini.

\section{METODE}

Pendekatan yang digunakan dalam penelitian ini adalah kualitatif dengan menggunakan metode studi kasus. Pendekatan ini dipilih untuk menghasilkan data akurat, mendalam, dan komprehensif yang berkaitan dengan tema penelitian. Lokasi penelitian adalah SMP Negeri 4 Sentani, Kabupaten Jayapura, Provinsi Papua. Informan dalam penelitian ini adalah siswa kelas VII, VIII, dan IX yang berjumlah 30 orang. Peneliti menggunakan teknik wawancara secara mendalam, observasi, dan studi dokumentasi berupa pengumpulan data-data atau dokumentasi yang berkaitan tema penelitian ini. Sementara teknik analisis data menurut tahapan yang digunakan Miles dan Huberman (1992), yaitu (1) reduksi data, (2) sajian data, (3) penarikan kesimpulan dan verifikasi untuk menjelaskan data penelitian terkait ancaman bullying sebagai noktah hitam pendidikan karakter. 
CIVICS EDUCATION AND SOCIAL SCIENSE JOURNAL(CESSJ)

Volume 3 Nomor 1 Edisi Bulan Juni 2021

\section{HASIL PENELITIAN DAN PEMBAHASAN}

\section{Masalah dan Upaya Pemberdayaan Karakter}

Istilah karakter berasal dari bahasa Yunani charassein, yang berarti to engrave atau mengukir. Membentuk karakter diibaratkan seperti mengukir di atas batu permata atau permukaan besi yang keras. Dari sanalah kemudian berkembang pengertian karakter yang diartikan sebagai tanda khusus atau pola perilaku (Komalasari, 2011: 422; Hakam, 2011: 392). Allport (1948), seorang tokoh psikologi dari Amerika yang mengembangkan teori kepribadian, mendefisikan karakter sebagai penentu bahwa seseorang sebagai pribadi (character is personality evaluated). Menurut Philip (2008: 235), karakter merupakan kumpulan tata nilai yang menuju pada suatu sistem, yang melandasi pemikiran, sikap, dan perilaku yang ditampilkan.

Rae (2009: 17) menuliskan, "character is the tendency of a person to act in predictable ways over time". Karakter merupakan sikap dan perilaku yang dipertimbangkan orang dalam berbagai pengambilan keputusan. Konsep karakter baik (good character) dipopulerkan Lickona (1992) merujuk pada konsep yang dikemukakan Aristoteles sebagai "the life of right conduct-in relation to other persons and in relation to oneselft" atau kehidupan berperilaku baik/penuh kebajikan, yakni berperilaku baik terhadap pihak lain (Tuhan Yang Maha Esa, manusia, dan alam semesta) dan terhadap diri sendiri.

Kehidupan yang penuh kebajikan (the virtuous life) sendiri oleh Lickona (1991), dibagi kedalam dua kategori, yaitu kebajikan terhadap diri sendiri (selforiented virtuous) seperti pengendalian diri (self control) dan kesabaran (moderation); dan kebajikan terhadap orang lain (other-oriented virtuous) seperti kesediaan berbagi (generousity) dan merasakan kebajikan (compassion). Sementara itu, pendidikan karakter merupakan roh, semangat, atau spirit yang menjiwai dan akan menggerakan serta mengarahkan pendidikan (Sukandi, 2011: 98). Di sini, pendidikan tanpa roh, spirit atau jiwa tentu tidak akan berjalan sebagaimana mestinya. Roh pendidikan karakter dapat menjadi pisau bermata dua (Koesoema, 2010: 115).

Di satu sisi, pendidikan karakter dapat memacu dan meningkatkan kemampuan intelektual dan akademis, namun sisi lain pendidikan karakter dapat menjadi usaha pertahanan dan pengembangan kapasitas moral peserta didik. Kedua kekuatan ini dapat menjadi idealisme pendidikan agar dapat mengarahkan peserta didik semakin mampu mengembangkan ketajaman intelektual dan integritas diri sebagai pribadi yang memiliki karakter kuat. Demikian pula pendidikan tanpa spirit dan jiwa yang jelas dalam bentuk pendidikan karakter diyakini akan menjadi bumerang bagi kepentingan kemanusiaan itu sendiri (Sukandi, 2011: 98). Hal ini sangat jelas dinyatakan oleh Mahatma Gandhi bahwa pendidikan tanpa basis karakter merupakan salah satu dosa yang fatal.

JORNAL PROGDI PPKn, FKIP UNIVET BANTARA SUKOHARJO BEKERJA SAMA DENGAN ASSOSIASI PROFESI PENDIDIKAN PANCASILA DAN KEWARGANEGARAAN (AP3KNI) JAWA TENGAH 
Pendidikan karakter sesungguhnya merupakan proses pemberdayaan (empowering) potensi peserta didik, proses humanisasi (humanizing), dan proses pemberdayaan (civilizing). Sebagai proses pemberdayaan, pendidikan karakter pada dasarnya adalah usaha sadar untuk memberdayakan dan mengembangkan seluruh potensi peserta didik. Proses ini juga memberdayakan peserta didik sebagai makhluk yang menyadari sejumlah potensi dan menyadari keterbatasannya. Pendidikan karakter juga dapat dipahami sebagai proses humanisasi dalam rangka memanusiakan manusia menjadi manusiawi. Di sini, proses pendidikan tidak menjadikan peserta didik robot bagi kehendak orang dewasa, melainkan menjadikan peserta didik sebagai subjek yang bebas, mandiri, kritis. Sementara, pendidikan karakter sebagai proses pemberdayaan merupakan internalisasi, pembiasaan, dan pembudayaan (Sukandi, 2011: 100).

Inti pendidikan karakter seperti uraian di atas mesti dipraktekkan oleh pihak sekolah. Namun penelitian menemukan, pendidikan karakter yang diterapkan di SMP Negeri 4 Sentani belum memiliki daya tawar berharga bagi pembentukan karakter seluruh warga sekolah. Peserta didik belum mendapatkan banyak keuntungan dengan memperoleh perilaku dan kebiasaan positif yang mampu meningkatkan rasa percaya diri dan membuat proses belajar menjadi produktif. Sementara itu, tugas pendidik menjadi lebih berat dalam proses empowering, humanizing, dan civilizing. Karena, kualifikasi keahlian guru bukan sebagai pendidik Pendidikan Karakter. Padahal, efetivitas pendidikan karakter sangat ditentukan oleh proses empowering, humanizing, dan civilizing.

Hal ini berdampak luas bagi para orang tua yang belum bergembira melihat anak mereka belajar menjadi lebih sopan, memiliki rasa hormat, dan lebih produktif. Belum lagi, aktivitas guru di kelas masih menekankan pada "proses mengajar" dan mengesampingkan "proses mendidik". Di sini, guru belum memiliki kepekaan dalam proses memanusiakan manusia. Di tambah lagi, guru belum mampu menyadarkan siswa akan keberadaan dan realitas sosialnya sendiri sehingga ia dapat melakukan perubahan menuju kehidupan masa depan yang lebih baik.

Temuan lainnya adalah bentuk pengajaran pendidikan karakter di sekolah masih mengandalkan bentuk pengajaran nilai-nilai pada mata pelajaran tentu, semisal PKn. Padahal, pengajaran nilai-nilai hanyalah salah satu bentuk atau strategi pendidikan karakter. Lebih efektif jika pendidikan karakter dapat dilaksanakan secara terintegrasi dan kolaboratif melalui metode pembelajaran di kelas, penciptaan budaya sekolah, metode berbasis masyarakat, dan dukungan berbagai kebijakan pendidikan terkait. Persoalan lebih lanjut adalah pendekatan keteladan baik pola berpikir dan bertindak sesuai dengan nilai dan norma yang mendasari pembentukan karakter belum efektif dipraktikkan oleh guru di sekolah. Keadaan ini berdampak pada iklim sekolah yang masih tercemar oleh tindakan tidak terpuji dintara para pelajar, semisal bullying, baik dalam bentuk fisik, verbal maupun mental/psikologis.

JORNAL PROGDI PPKn, FKIP UNIVET BANTARA SUKOHARJO BEKERJA SAMA DENGAN ASSOSIASI PROFESI PENDIDIKAN PANCASILA DAN KEWARGANEGARAAN (AP3KNI) JAWA TENGAH 
Sukandi (2011: 104) menegaskan, kondisi buruk seperti ini yang menyebabkan proses penanaman nilai-nilai keutamaan pendidikan karakter anak bangsa menjadi lemah dan terkendala serta menghambat efektivitas pencapaian tujuan pendidikan karakter. Lebih lanjut Sukandi mengusulkan dalam mencapai tujuan dan kompetensi yang diharapkan, maka pendidikan karakter sebagai pemberdayaan potensi manusia, proses manusiawi, dan proses pembudayaan dijalakan dengan berbagai pendekatan dan model pembelajaran. Terdapat empat pendekatan pendidikan karakter yang dapat dilaksanakan secara sinergis yaitu pendekatan berbasis kelas, kultur sekolah, komunitas, dan dukungan kebijakan pendidikan.

Beberapa model pembelajaran pendidikan karakter yang diterapkan antara lain: model pembelajaran penanaman nilai, perkembangan penalaran moral, analisis nilai, project citizen, dan model pembelajaran berbasis budaya-spiritual. Keberhasilan pembelajaran pendidikan karakter dalam pencapaian tujuan dan pembentukan kompetensi kepribadian peserta didik perlu dievaluasi dengan menggunakan prinsip-prinsip: penilaian dilakukan secara utuh, komprehensif, dan multidimensional, bermakna, autentik, berkesinambungan serta harus bersifat mendidik. Dengan kata lain, efektivitas, efisiensi, dan relevansi pelaksanaan pendidikan karakter hendaknya dievaluasi secara berkesinambungan untuk kepentingan evaluasi dan refleksi diri sehingga selalu dapat ditingkatkan dan disempurnakan guna mendukung peningkatan mutu pendidikan di sekolah.

\section{Perilaku Bullying: Noktah Hitam}

Sektor pendidikan memainkan peran sentral dalam membentuk karakter baik (good character) anak bangsa sesuai dengan tata nilai ke-Indonesiaan agar di masa mendatang mereka mampu hidup berdampingan secara damai dan harmonis dengan semua warga. Namun, kenyataan sering bertolak belakang dengan idealisme pendidikan dimaksud, masih dijumpai karakter anak bangsa yang tidak sesuai dengan tata nilai ke-Indonesiaan.

Kekerasan (bullying) di sekolah menjadi salah satu fenomena memprihatinkan dalam dunia pendidikan yang menyita perhatian banyak pihak. Supardan (2011: 318), mengeluhkan peran sekolah dewasa ini ibarat "lebah tanpa sengat" bahkan mendekati "mati suri" dalam menghadapi tantangan yang makin berat dan kompleks. Hasil riset Ersotelos dkk, (2021: 17) menyimpulkan, bullying di kalangan pelajar bukanlah fenomena baru, bahkan ada peningkatan setiap tahun. Jika tindakan ini tidak mampu dicegah, maka sekolah dapat menjadi tempat yang berbahaya bagi anak-anak. Bullying ibarat virus yang dapat menyerang dan merusak sel-sel dalam tubuh, diperlukan tindakan preventif dan represif dari pihak sekolah untuk mengatasi tindakan dimaksud, jika dibiarkan berlarut maka secara kolektif akan berdampak negatif bagi karakter anak bangsa.

Bullying mengacu pada tindakan agresif secara verbal, fisik, atau psikologis yang berulang setiap waktu dan dimaksudkan untuk menyebabkan kerugian atau 
kesusahan bagi korban yang tidak dapat membela diri (Olweus, 1992; Farrington, 1993; Centers for Disease Control and Prevention, 2014). Korban bullying akan menderita tekanan psikologis dan memiliki banyak efek berbahaya, yang dapat bertahan hingga dewasa (Arseneault 2018), termasuk depresi (Ttofi dkk, 2011a; Bowes dkk, 2015 ); kecemasan (Stapinski dkk, 2014 ); menyakiti diri sendiri (Fisher dkk, 2012 ); ide untuk membunuh diri (Ttofi dkk, 2011a ); tersinggung (Ttofi dkk, 2011b ); dan perilaku yang merusak kesehatan, seperti mengonsumsi minuman keras, merokok, dan menggunakan obat terlarang (Vieno dkk, 2011; Ttofi dkk, 2016 ). Hal ini juga telah menyebabkan peningkatan ketidakhadiran di sekolah (Brown dkk, 2011), pencapaian prestasi yang lebih rendah (Nakamoto dan Schwartz 2010), dan gangguan kesehatan mental (Evans-Lacko dkk, 2017).

Berdasarkan pengalaman, bullying terjadi karena terdapat ketidakseimbangan kekuatan antara pelaku bully dan korban, sehingga pelaku bully menggunakan kekerasan untuk mengontrol korban dan membuatnya menjadi lemah (Annerbäck, 2014). Penelitian menemukan, bullying yang terjadi di SMP Negeri 4 Sentani disebabkan beberapa hal. Kesatu, ada pelajar yang merasa dirinya sangat baik, sangat kuat, dan sangat berkuasa, sehingga mencari pelajar lain yang lebih lemah dan rentan. Kedua, bullying fisik yang terjadi merupakan tindakan balas dendam atas perlakuan buruk yang dilakukan lebih awal oleh teman mereka, itu artinya telah terjadi tindakan bullying yang dilakukan secara berulang-ulang oleh teman mereka. Ketiga, bullying verbal yang terjadi di kalangan para pelajar ketika mereka merasa teraniaya, takut, terintimidasi oleh tindakan teman mereka. Bullying verbal mudah dilakukan dan dapat dibisikkan dihadapan orang lain, tanpa terdeteksi.

Keempat, bullying mental atau psikologis semisal tindakan mengucilkan teman (memisahkan atau mengeluarkan dari kelompok pertemanan) atau tindakan mencibir (mengejek menggunakan bibir) karena suasana hati mereka masih labil ketika dibully, sehingga mereka membalasnya dengan melakukan hal yang serupa. Artinya, pelajar yang memiliki kontrol diri yang rendah, berpotensi menjadi pembully. Kelima, fenomena bullying tidak hanya dilihat dari sudut pandang individu pelaku dan korban, tetapi hal itu lebih menitikberatkan pada aspek sosial yang melatarbelakangi fenomena tersebut terjadi. Iklim sosial dan sekolah sering menjadi indikator yang memicu perilaku bullying. Kontrol atau disiplin sekolah yang lemah dan contoh buruk yang sering ditemui oleh pelajar di masyarakat, membuat mereka cendering meniru atau mencoba kepada teman mereka di sekolah.

Keenam, temuan unik lainnya adalah ada pelajar yang membully menggunakan bahasa daerah Sentani, Papua. Hal ini sebagai bahan ejekan maupun lelucon yang tidak dapat dipahami oleh teman mereka. Ketujuh, keterlibatan sebagian besar para pelajar secara aktif di media sosial terutama Facebook membuat mereka sering menyaksikan konten kekerasan dan bentuk video maupun gambar. Ditambah lagi, kemudahan mengakses konten lelucon (prank) bernuansa

JORNAL PROGDI PPKn, FKIP UNIVET BANTARA SUKOHARJO BEKERJA SAMA DENGAN ASSOSIASI PROFESI PENDIDIKAN PANCASILA DAN KEWARGANEGARAAN (AP3KNI) JAWA TENGAH 
kekerasan yang dibuat oleh berbagai pengguna Youtube (youtuber) yang menjadi viral sering dipraktekkan oleh mereka di dalam lingkungan sekolah.

Bullying sama sekali tidak dibenarkan meskipun terdapat beberapa alasan tertentu yang melatarbelakanginya (Thalib, 2010: 191). Tindakan ini sebagai bukti nyata noktah hitam pendidikan karakter di Indonesia. Sayangnya pendidikan kita yang dikemas dalam berbagai model dan pendekatan di dalam pelajaran PKn belum matang untuk meminimalisasi tindakan bullying. Sebab, prosesnya masih menitikberatkan pada aspek kognitif dan mengesampingkan afektif dan psikomor. Padahal proses pendidikan tidak sekedar mentransfer ilmu, namun pembentukan keterampilan dan internalisasi nilai-nilai dasar kemanusiaan kepada peserta didik. Belum lagi, prosesnya masih mengabaikan pembentukan watak kewarganegaraan (civic disposition), padahal watak merupakan salah satu ranah yang amat menentukan keberhasilan warga negara dalam belajar (Malatuny \& Rahmat, 2017: 66).

Sementara itu, corporal punishment sebagai hukuman yang paling banyak dilakukan pendidik di sekolah terhadap para pelajar dengan menggunakan kekerasan dengan sebuah alasan karena hendak mendisiplinkan siswa (Sucipto, 2012: 3) belum banyak menolong para pelajar untuk keluar dari noktah hitam ini. Karena itu, diperlukan sentuhan pendidik dengan cara-cara yang lebih manusiawi untuk meminimalikan tindakan bullying. Dalam menciptakan kultur sekolah yang kondusif, para pendidik mesti mengatur dan memfasilitasi penyelenggaraan kegiatan yang mendorong terciptanya kultur sekolah yang memungkinkan tumbuhnya karakter baik, sehingga dapat mencegah perilaku bullying diantara pelajar, seperti workshop, diskusi antar guru, pengembangan kurikulum dan pengajaran, gerakan kebersihan sekolah, kegiatan ibadah, pembinaan organisasi siswa, penegakan disiplin, pelenggaraan olahraga, perlombaan kesenian, penyelenggaraan pendidikan kecakapan hidup, dan sejenisnya (Suryadi, 2011: 127).

Lebih lanjut, sebuah kajian menjelaskan untuk mencegah perilaku bullying langkah-langkah yang mesti dilakukan oleh pendidik di sekolah seperti; Merancang dan membuat desain program pencegahan yang berisikan pesan kepada murid bahwa perilaku bully tidak diterima di sekolah dan membuat kebijakan "anti bullying"; Membangun komunikasi efektif antara pendidikan dan peserta didik; Diskusi dan ceramah mengenai perilaku bully di sekolah; Menciptakan suasana lingkungan sekolah yang aman, nyaman dan kondusif; Menyediakan bantuan kepada murid yang menjadi korban bully; dan Melakukan pertemuan berkala dengan orangtua atau komite sekolah. 


\section{SIMPULAN}

Berdasarkan temuan penelitian dan pembahasan yang telah diuraikan, maka dapat ditarik kesimpulan sebagai berikut. Kesatu, sekolah menjadi garda terdepan dalam menanamkan karakter baik (good character) kepada para pelajar. Sekolah menjadi benteng moral dan memiliki tanggung jawab besar dalam menginternalisasikan nilai, moral, dan sikap yang berkeadaban mulya kepada setiap generasi bangsa. Tidak adil jika pendidikan karakter di sekolah, hanya dibebankan kepada mata pelajaran tertentu semata. Pendidikan karakter mesti ditanamkan oleh seluruh guru bahkan semua pemangku kepentingan dalam pendidikan termasuk orang tua dan masyarakat. Kedua, peserta didik belum memperoleh keuntungan yang banyak dengan melalui perilaku dan kebiasaan positif yang mampu meningkatkan rasa percaya diri dan membuat proses belajar menjadi produktif di sekolah. Karena pendidik belum efektif menjadikan pendidikan karakter sebagai proses empowering, humanizing, dan civilizing, selain itu kualifikasi keahlian pendidik bukan sebagai pendidik Pendidikan Karakter.

Ketiga, bullying di sekolah telah menjadi salah satu fenomena memprihatinkan dalam dunia pendidikan baik berskala lokal, nasional maupun internasiol yang sangat menyita perhatian banyak pihak. Bullying sebagai bukti nyata noktah hitam pendidikan karakter bangsa, sebab masih saja terjadi tindakan agresif secara verbal, fisik, atau psikologis yang berulang setiap waktu. Peran sekolah dewasa ini ibarat "lebah tanpa sengat" bahkan mendekati "mati suri" dalam menghadapi tantangan bullying yang makin berat dan kompleks. Keempat, berbagai model pembelajaran pendidikan karakter yang diterapkan seperti model pembelajaran penanaman nilai, perkembangan penalaran moral, analisis nilai, project citizen, dan model pembelajaran berbasis budaya-spiritual direkomendasikan kepada pendidik di sekolah untuk meminimalkan tindakan bullying. Selain itu, keberhasilan pembelajaran pendidikan karakter dalam mencapai tujuan dan pembentukan kemampuan kepribadian siswa perlu dievaluasi dengan menggunakan prinsip-prinsip sebagai berikut: evaluasi dilakukan secara komprehensif, multidimensi, bermakna, benar, dan berkesinambungan.

Kelima, dalam menciptakan budaya sekolah yang aman dan nyaman, pendidik harus mengatur dan mempromosikan kegiatan yang mendorong terciptanya budaya sekolah yang menumbuhkan karakter yang baik untuk mencegah perundungan di kalangan siswa, seperti lokakarya, diskusi antar guru, pengembangan kurikulum dan pengajaran, kampanye kebersihan sekolah, kegiatan ibadah, pelatihan organisasi siswa, penguatan disiplin, penyelenggaraan olahraga, perlombaan seni, dan penyelenggaraan pendidikan kecakapan hidup.

JORNAL PROGDI PPKn, FKIP UNIVET BANTARA SUKOHARJO BEKERJA SAMA DENGAN ASSOSIASI PROFESI PENDIDIKAN PANCASILA DAN KEWARGANEGARAAN (AP3KNI) JAWA TENGAH 
CIVICS EDUCATION AND SOCIAL SCIENSE JOURNAL(CESSJ)

Volume 3 Nomor 1 Edisi Bulan Juni 2021

\section{REFERENSI}

Allport, G.W. (1948). Personality: A Psychlogical Interpretation. New York: Henry Holt and Company.

Anggraini, D. Amallia dan Ridha, Mursyid. (2021). The Relationship of School Discipline with Bullying Behavior At SMP N 26 Padang. Jurnal Neo Konseling, 3(1), 8-14.

Annerbäck, E.-M, Sahlqvist, L, \& Wingren, G. (2014). A cross-sectional study of victimisation of bullying among schoolchildren in Sweden: Background factors and self-reported health complaints. Scand. J. Public Health, 42, 270-277.

Arseneault, L. (2018). Annual research review: The persistent and pervasive impact of being bullied in childhood and adolescence: Implications for policy and practice. Journal of Child Psychology and Psychiatry, 59(4), 405421.

Bowes, L., Joinson, C., Wolke, D., \& Lewis, G. (2015). Peer victimisation during adolescence and its impact on depression in early adulthood: Prospective cohort study in the United Kingdom. BMJ, 350: h2469.

Brown, V., Clery, E., \& Ferguson, C. (2011). Estimating the prevalence of young people absent from school due to bullying. London: National Centre for Social Research.

Budimansyah, Dasim. (2010). Penguatan Pendidikan Kewarganegaraan Untuk Membangun Karakter Bangsa. Bandung: Widya Aksara Press.

Centers for Disease Control and Prevention. (2014). Bullying surveillance among school-aged children: Uniform definitions and recommended data elements. Washington, DC: CDC.

Ersotelos, Nikolaos et all. (2021). Blockchain and IoMT against Physical Abuse: Bullying in Schools as a Case Study. Journal of Sensor and Actuator Netw, 10(1), 1-20.

Evans-Lacko, S., Takizawa, R., Brimblecombe, N., King, D., Knapp, M., Maughan, B., \& Arseneault, L. (2017). Childhood bullying victimization is associated with use of mental health services over five decades: A

JORNAL PROGDI PPKn, FKIP UNIVET BANTARA SUKOHARJO BEKERJA SAMA DENGAN ASSOSIASI PROFESI PENDIDIKAN PANCASILA DAN KEWARGANEGARAAN (AP3KNI) JAWA TENGAH 
CIVICS EDUCATION AND SOCIAL SCIENSE JOURNAL(CESSJ)

Volume 3 Nomor 1 Edisi Bulan Juni 2021

longitudinal nationally representative cohort study. Psychological Medicine, 47(1), 127-135.

Farrington, D. P. (1993). Understanding and preventing bullying. Crime and Justice, 17, 381-458.

Fisher, H. L., Moffitt, T. E., Houts, R. M., Belsky, D.W., Arseneault, L., \& Caspi, A. (2012). Bullying victimisation and risk of self harm in early adolescence: Longitudinal cohort study. BMJ, 344, e2683.

Hakam, A. Kama. (2011). Membina Kecerdasan dan Perilaku Sosial Dalam Membangun Karakter Anak, Pendidikan Karakter: Nilai Inti bagi Upaya Pembinaan Kepribadian Bangsa, Penghargaan dan Penghormatan 70 tahun Prof. Dr. H. Endang Somantri, M.Ed. Bandung: Widya Aksara Press.

Hasyim, Adelina. (2011). Gerakan Membangun Karakter Bangsa, Pendidikan Karakter: Nilai Inti bagi Upaya Pembinaan Kepribadian Bangsa, Penghargaan dan Penghormatan 70 tahun Prof. Dr. H. Endang Somantri, M.Ed. Bandung: Widya Aksara Press.

Koesoema, A. Doni. (2010). Pendidikan Karakter Strategi Mendidik Anak di Zaman Global. Jakarta: Grasindo.

Komalasari, Kokom. (2011). Pendidikan Karakter di Persekolahan China, Pendidikan Karakter: Nilai Inti bagi Upaya Pembinaan Kepribadian Bangsa, Penghargaan dan Penghormatan 70 tahun Prof. Dr. H. Endang Somantri, M.Ed. Bandung: Widya Aksara Press.Bandung: Widya Aksara Press.

Lickona, Thomas. (1991). Educating for Character: How Our School can Teach Respect and Responsibility. New York: Bantam Books.

Malatuny, Y. G., \& Rahmat, R. (2017). Pembelajaran Civic Education Dalam Mengembangkan Civic Disposition. PEDAGOGIKA: Jurnal Pedagogika dan Dinamika Pendidikan, 5(1), 56-68.

Malatuny, Yakob Godlif. (2020). Percikan Gagasan: Menelaah Problematika Kontemporer Kewarganegaraan. Yogyakarta: Deepublish.

Nafingah, A.A Bunga dan Suroso, Jebul. (2020). Pengaruh Behavior Skill Training Terhadap Interaksi Sosial Korban Bullying Di SMP Negeri 1

JORNAL PROGDI PPKn, FKIP UNIVET BANTARA SUKOHARJO BEKERJA SAMA DENGAN ASSOSIASI PROFESI PENDIDIKAN PANCASILA DAN KEWARGANEGARAAN (AP3KNI) JAWA TENGAH 
CIVICS EDUCATION AND SOCIAL SCIENSE JOURNAL(CESSJ)

Volume 3 Nomor 1 Edisi Bulan Juni 2021

Kaligondang Kabupaten Purbalingga. Jurnal Keperawatan Muhammadiyah, 5(2), 165-170.

Nakamoto, J., \& Schwartz, D. (2010). Is peer victimization associated with academic achievement? A meta-analytic review. Social Development, 19(2), 221-242.

Olweus, D. (1992). Bullying among school children: Intervention and prevention. In R.D. Peters, R. J. McMahon, \& V.L. Quinsey (Eds.), Aggression and violence throughout the lifespan. London: Sage.

Parrott III, L. (2000). Helping Your Struggling Teenager: A Parenting Handbook On Thirty-Six Common Problems. Grand Rapids: Zondervan Publishing House.

Philip, Simon. (2008). Refleksi Karakter Bangsa. Jakarta: Gramedia.

Prasetyo, E. Utomo. (2019). Internalization Of National Character Value In Social Studies To Build The Identity Of Indonesia. Jurnal Pendidikan Karakter, 5(2), 1-12.

Rae, B. Scott. (2009). Moral Choices: An Introduction to Ethics. Grand Rapids, Michigan: Zondervan.

Roberts, H.S Luke. (2020). Bullying in Schools: A complexity approach to sustainable restorative approaches?. Dissertation. England: Faculty of Education University of Cambridge.

Sakdiyah, Fatimatus dkk. (2020). Resiliensi dan Kejadian Bullying pada Remaja SMP di Demak. Bima Nursing Journal, 1(2), 119-125.

Singham T, Viding E, Schoeler T, et al. (2017). Concurrent and longitudinal contribution of exposure to bullying in childhood to mental health. JAMA Psychiatry, 74:E1-E8.

Sofyan, Sauri. (2011). Strategi dan Implementasi Pendidikan Karakter Bangsa di Perguruan Tinggi, Pendidikan Karakter: Nilai Inti bagi Upaya Pembinaan Kepribadian Bangsa, Penghargaan dan Penghormatan 70 tahun Prof. Dr. H. Endang Somantri, M.Ed. Bandung: Widya Aksara Press.

Stapinski, L. A., Bowes, L., Wolke, D., Pearson, R. M., Mahedy, L., Button, K. S., et al. (2014). Peer victimization during adolescence and risk for anxiety

JORNAL PROGDI PPKn, FKIP UNIVET BANTARA SUKOHARJO BEKERJA SAMA DENGAN ASSOSIASI PROFESI PENDIDIKAN PANCASILA DAN KEWARGANEGARAAN (AP3KNI) JAWA TENGAH 
CIVICS EDUCATION AND SOCIAL SCIENSE JOURNAL(CESSJ)

Volume 3 Nomor 1 Edisi Bulan Juni 2021

disorders in adulthood: A prospective cohort study. Depression and Anxiety, 31(7), 574-582.

Sucipto. (2012). Bullying dan Upaya Meminimalisasikannya. Jurnal Psikopedagogia, 1(1), 1-12.

Sukandi. (2011). Pendidikan Karakter Bangsa Beideologi Pancasila, Pendidikan Karakter: Nilai Inti bagi Upaya Pembinaan Kepribadian Bangsa, Penghargaan dan Penghormatan 70 tahun Prof. Dr. H. Endang Somantri, M.Ed. Bandung: Widya Aksara Press.

Supardan, Dadang. (2003). Turbulensi dan Bahaya Kekeresan dalam Pendidikan, dalam Helius Sjamsuddin dan Andi Suwirta, Historia Magistra Vitae, Menyambut 70 tahun Prof. Dr. Hj. Rochiati Wiriaatmadja, MA. Bandung: Historia Press.

Supardan, Dadang. (2011). Mengintip Bahaya Kekerasan sebagai Ancaman Pendidikan Karakter Bangsa: Anatomi Perspektif Ilmu-ilmu Sosial. Pendidikan Karakter: Nilai Inti bagi Upaya Pembinaan Kepribadian Bangsa, Penghargaan dan Penghormatan 70 tahun Prof. Dr. H. Endang Somantri, M.Ed. Bandung: Widya Aksara Press.

Suryadi, Ace. (2011). Pendidikan Karakter Bangsa: Pendekatan Jitu menuju Sukses Pembangunan Pendidikan Nasional. Pendidikan Karakter: Nilai Inti bagi Upaya Pembinaan Kepribadian Bangsa, Penghargaan dan Penghormatan 70 tahun Prof. Dr. H. Endang Somantri, M.Ed. Bandung: Widya Aksara Press.

Ttofi, M. M., Farrington, D. P., Lösel, F., \& Loeber, R. (2011a). Do the victims of school bullies tend to become depressed later in life? A systematic review andmeta-analysis of longitudinal studies. Journal of Aggression, Conflict and Peace Research, 3(2), 63-73.

Ttofi, M. M., Farrington, D. P., Lösel, F., \& Loeber, R. (2011b). The predictive efficiency of school bullying versus later offending: A systematic/ meta-analytic review of longitudinal studies. Criminal Behaviour and Mental Health, 21(2), 80-89.

Ttofi, M. M., Farrington, D. P., Lösel, F., Crago, R. V., \& Theodorakis, N. (2016). School bullying and drug use later in life: A meta-analytic investigation. School Psychology Quarterly, 31(1), 8-27. 
CIVICS EDUCATION AND SOCIAL SCIENSE JOURNAL(CESSJ)

Volume 3 Nomor 1 Edisi Bulan Juni 2021

Vieno, A., Gini, G., \& Santinello, M. (2011). Different forms of bullying and their association to smoking and drinking behavior in Italian adolescents. Journal of School Health, 81(7), 393-399. 